\title{
Time Series Movements in Art Prices
}

\author{
Alena POZDÍLKOVÁ*, Jaroslav MAREK and Marie NEDVĚDOVÁ \\ University of Pardubice, Pardubice, Czech Republic; alena.pozdilkova@upce.cz, jaroslav.marek@upce.cz; \\ marie.nedvedova@upce.cz \\ * Corresponding author: alena.pozdilkova@upce.cz
}

\begin{abstract}
The aim of our paper is to understand the price behavior of artworks, mainly graphics sold in one selected Czech auction house. The publicly available information obtained from internet auction systems provide price time series of monitored painters works. We focused on the prediction of the price development using linear regression methods. Approach presented in our paper provided finding an artist whose painting prices are rising statistically significantly. We worked with a dataset of total of 398 paintings by 10 Czech painters. Authors with at least 11 auctioned paintings will be used for statistical analysis. We did not focus on art auctions with the most expensive paintings, but on paintings and graphics that are affordable for the general population. The graphics dominated the data collected. The goal of our study is to estimate the annual change in works of art in the Czech Republic and compare with respect to inflation in the period from 2014 to 2020. In the final discussion, an assessment of the further price development of works of art is also discussed.
\end{abstract}

Keywords: Art work prices; time series; trend component

JEL Classification: Z11; E27; D44

\section{Introduction}

Comparing investment expectations for selected stocks, bonds, real estate, the development of currency pairs, etc. formulates investors' investment portfolio, cf. (Szumilo, 2018). However, investing can also be collector-oriented. Financial products are more accessible and have more publicity; thus, analyzes of the evaluation of the investment potential of works of art are not often published. But even for a small investor, works of art, especially graphics, are available at auctions of various auction houses. Therefore, in this article, we focused on the analysis of fine art prices at auctions in the Czech Republic.

The heterogeneity of the characteristics of works of art and the low frequency of trade in the same works of art are viewed as major obstacles to market analysis. The global development of the art market can be traced through the amount of money invested in the world art auctions, which provides a reasonable way to construct various art price indices. Collecting time series allows then to estimate the relative increase in prices.

We are inspired by the survey from Ashenfelter (2002), in which the estimated returns of art from 14 various studies are presented on page 12 . The smallest estimate is 0.5 percent and the largest is 5.0 percent per year. Two of these 14 analyzes are presented in the articles (Mei, 2003) and (Stein, 1977). The results (Mei, 2003) on the return and risk characteristics of works 
of art and the correlations between artistic and financial assets have implications for longterm investors. Stein (1977) calculated appreciation above 1.6 percent for pre-World War II painting from the USA.

Another study of Garay (2019) analyzed 5,961 artworks executed by 69 Venezuelan artists, which were sold at auctions between years 1969 and 2014. Author used a hedonic price regression. Hedonic price regression was also used in Chanel (1995). The results showed that art market is correlated with economic indicators; however, it is very difficult to predict in long-term forecasts.

In Bialynicka-Birula (2018), the European art market in the period 2002-2015 was examined. It was found that sales on the global art market generally increased, but the art market was considerably affected by the economic recession in 2009.

In Candela (1997), a price index for Italian art market auctions was computed. He found out that in period 1983-1994, art prices increased in the same line as inflation. Art price indices, such as representativeness, liquidity or capacity were described in one part of (McAndrew, 2010). Author indicated advantages and disadvantages of repeat sales and indices like hedonic price indices or hybrid models.

Another interesting aspect is how an artist's death affects the price of her works of art. This aspect was studied by (Itaya, 2016). In our article, we have similar situation, assessing, how much a death of one of our selected authors Olbram Zoubek can affect the price of his works.

Art auctions are also monitored from the point of view of price development during the auction from the starting price to the final price, see Onofri (2009). An oft-cited article on the development of art prices is Agnello (1996), which focuses on the US market and an estimate of its annual growth. Obtaining such an estimate for the Czech art market is the aim of this article.

Our goal is to analyze a relatively short period of development of prices of works of art by selected Czech painters. Time series analysis can help us predict the future prices of arbitrary commodities and works of art. The web systems of several Czech auction houses were used for source data mining. In our random selection, the most prestigious works does not fugue. On the other hand, it does not include unknown and secondary authors. In our study, we compared a total of 398 paintings by following 10 painters: František Tavík Šimon, František Tichý, František Gross, Josef Jíra, Kristian Kodet, Jiří Načeradský, Bohuslav Reynek, Jan Slavíček, Zdeněk Sýkora and Olbram Zoubek. We selected only authors who had at least 10 paintings available. We drew from publicly available data from the Platýz auction houses (Platyz, 2020). The influence of different image characteristics was removed in our analyzes by the transformation of the auctioned price into a price per square centimeter. Thus, from the searched prices of the works of the selected painter, we calculated the average price per square centimeter. Of course, the variability over time in such art prices is affected not only by movements in prices but rather by the quality of the objects. Using the ordinary squares method, we estimated the trend component for the selected author, which we subject to further statistical testing. 
The main goal of our analyzes is to estimate the price trend for the selected artist and to assess its statistical significance. Our calculations also allow us to estimate the average annual appreciation of a given artist.

\section{Methodology}

\subsection{Basic Idea}

Through the parsing of the art auction website, we acquired data for the past year containing the author identifier, the painting or graphics price, the picture area and the date of the sale. For auctioned items, the kind of artwork were obtained during parsing. For each author that appeared in at least two auctions, we calculated the average value and the standard deviation of the price of a one square centimeter of painting.

These values can be accumulated over a longer period. This gives us time series of prices for all the authors with more items. This data can be studied using basic methods for time series processing. Testing of statistical hypothesis in the reference period allow to evaluate the statistical significance of the trend. Of course, such a grip through the average price per unit area does not consider the quality of the artwork. Also, the price of a work of art does not increase linearly with the area. The quality of the regression model used could be small, especially for authors with a small number of images with different artistic quality and large variability in image size.

\subsection{Formatting of Mathematical Components}

We considered a linear regression model in the form of

$$
y=\beta_{0}+\beta_{1} x,
$$

where $x$ is the month from date 1.1.2014 and $y$ is average $1 \mathrm{~cm}^{2}$ prize of painting. The model given as $y=\beta_{0}+\beta_{1} x$ describes the dependence between the time and the prize of painting.

We calculated an ordinary square estimate $\hat{y}=\beta_{0}+\beta_{1} x$ of the regression line using well know formulas for $\beta_{0}$ a $\beta_{1}$ estimates.

Further, we worked with a confidence domain for regression line, i.e.,

$$
b_{0}+b_{1} x \mp t_{n-2}(\alpha) s \sqrt{\frac{1}{n}+\frac{(x-\bar{x})^{2}}{\sum x_{i}^{2}-n \bar{x}^{2}}}
$$

Our recent research focused on significant positive trend testing. Thus, we tested the hypothesis $H_{0}: \beta_{1}=0$ based on statistics:

$$
T=\frac{\left|b_{1}-\beta_{1}\right|}{S E_{\widehat{\beta}}}=\frac{b_{1}}{s} \sqrt{\sum x_{i}^{2}-n \bar{x}^{2}} \sim t_{n-2}
$$

where

$$
s^{2}=\hat{\sigma}^{2}=\frac{S S_{\text {res }}}{n-2}, \quad S S_{\text {res }}=\sum_{i=1}^{n}\left(y_{i}-\hat{y}_{i}\right)^{2}=\sum_{i=1}^{n} e_{i}^{2}
$$

The quality of estimated regression line is given by the index of determination 


$$
R^{2}=1-\frac{S S_{r e s}}{S S_{t o t}}
$$

where

$$
S S_{t o t}=\sum_{i=1}^{n}\left(y_{i}-\bar{y}\right)^{2}
$$

\section{Data and Results}

Furthermore, we performed an analysis of art price time series in the Czech Republic using the regression analysis.

\subsection{Data}

Firstly, we collected data for time series construction. The example of measured values for chosen author is given in Table 1 . The total number of painters analyzed was 25. Overall, in the period between January 1st, 2001 and December 31th, 2020, we loaded 345 sales in 25 auction days. From the obtained data in the structure of Table 2, we can get basic statistical characteristics (number of items, average painting area price of a given author, standard deviation in an obtained random sample of paintings). An example of these variables is given in Table 2.

We used following painters: František Tavík Šimon, František Tichý, František Gross, Josef Jíra, Kristian Kodet, Jiří Načeradský, Bohuslav Reynek, Jan Slavíček, Zdeněk Sýkora and Olbram Zoubek.

An example of obtained data is presented in Table 1. This example is for author J. Slavíček and 14 selected paintings between 2014 and 2020. The size of the painting and its price can be seen in the table.

Table 1. Source data J. Slavíček.

\begin{tabular}{|c|c|c|c|c|c|}
\hline Date & Size & Price & Date & Size & Price \\
\hline 15.11 .2018 & $26 \times 33$ & 73,000 & 14.01 .2020 & $31 \times 40$ & 15,500 \\
\hline 09.06 .2014 & $27 \times 35$ & 39,000 & 08.10 .2018 & $40 \times 50$ & 9,500 \\
\hline 19.01 .2017 & $23 \times 33$ & 19,000 & 12.11 .2019 & $15 \times 29$ & 14,000 \\
\hline 22.05 .2018 & $50 \times 70$ & 37,000 & 16.05 .2019 & $39 \times 49$ & 9,000 \\
\hline 19.01 .2017 & $19 \times 30$ & 33,000 & 11.05 .2020 & $36 \times 54$ & 18,500 \\
\hline 19.07 .2018 & $19 \times 22$ & 24,000 & 08.10 .2020 & $45 \times 55$ & 31,000 \\
\hline 07.06 .2016 & $23 \times 35$ & 19,000 & 23.11 .2016 & $54 \times 65$ & 45,000 \\
\hline
\end{tabular}

In Table 2 average prices of $1 \mathrm{~cm}^{2}$ for selected author J. Slavíček are shown.

Table 2. An example of summary data: J. Slavíček.

\begin{tabular}{|c|c|c|c|c|c|c|c|c|c|c|}
\hline Time & $5 / 14$ & $5 / 17$ & $11 / 17$ & $12 / 17$ & $6 / 18$ & $9 / 18$ & $2 / 19$ & $4 / 19$ & $6 / 19$ & $4 / 20$ \\
\hline $\begin{array}{c}\text { J. Slavíček: Price } \\
\text { of 1.cm }\end{array}$ & 4.71 & 4.80 & 9.52 & 10.57 & 12.53 & 23.6 & 25.42 & 41.87 & 57.41 & 57.89 \\
\hline
\end{tabular}

\subsection{Rregression Analysis}

We present the estimates of regression line for every author separately and also together. Authors with statistically increasing price per $1 \mathrm{~cm}^{2}$ of painting are depicted in solid line. 
Dotted lines form confidence domain for the regression line that are constructed for level of confidence 5 percent.

In Figures 1-5, we can see the dependence of the price on the time. Regression lines as well as (1- $\alpha)$-confidence domain with $\alpha=5 \%$ were constructed. Regression line for all painting is presented in Fig. 6, which shows an increase in price.
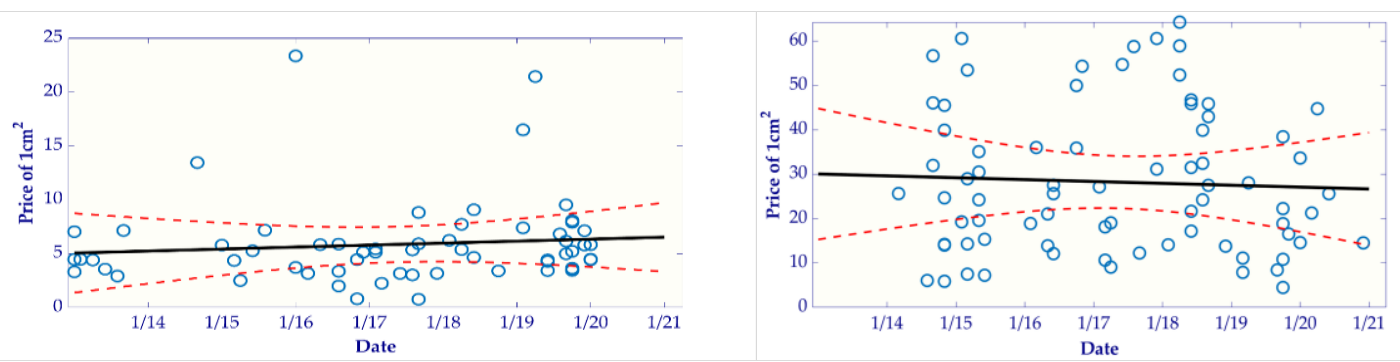

Figure 1. Regression line: Šimon and Tichý.
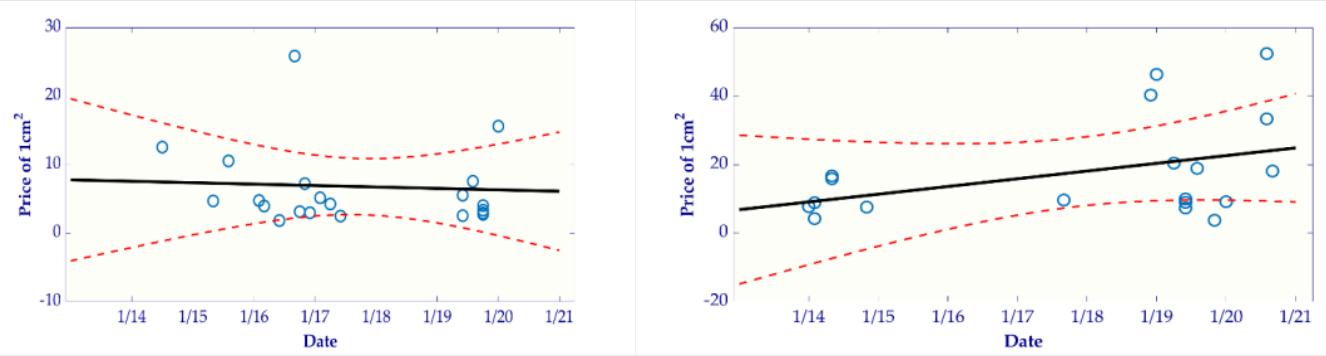

Figure 2. Regression line: Gross and Jíra.
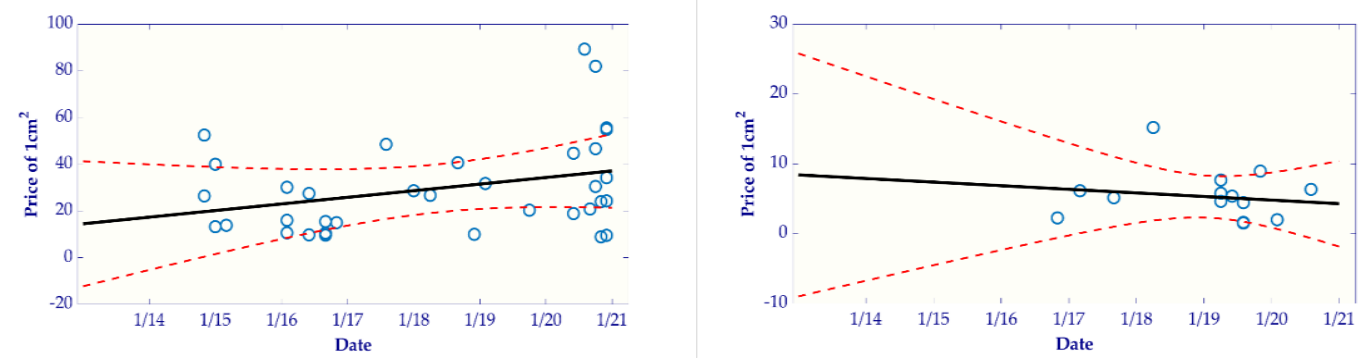

Figure 3. Regression line: Kodet and Načeradský.
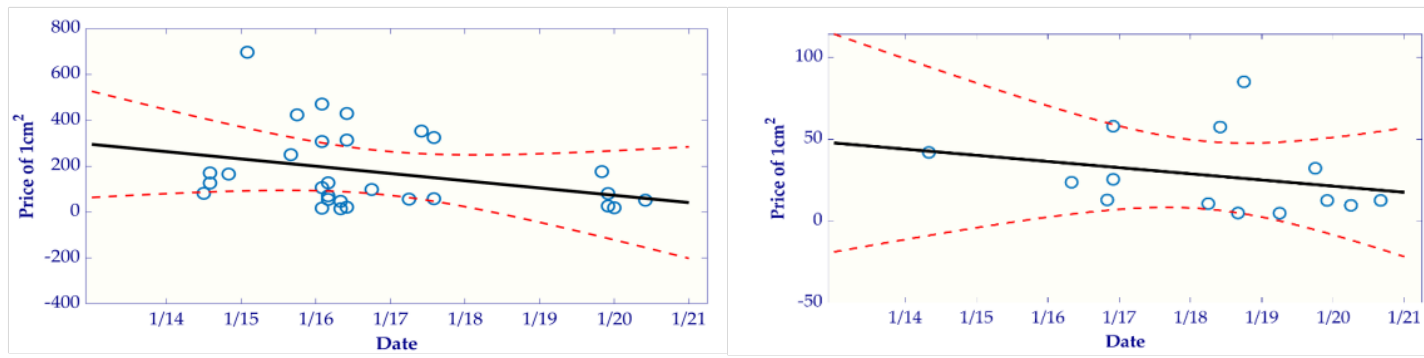

Figure 4. Regression line: Reynek, and Slavíček. 

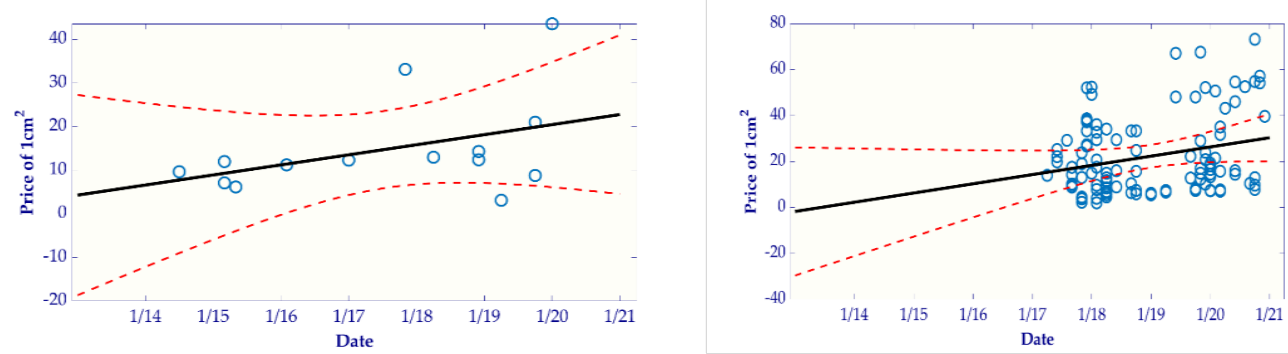

Figure 5. Regression line: Sýkora and Zoubek.

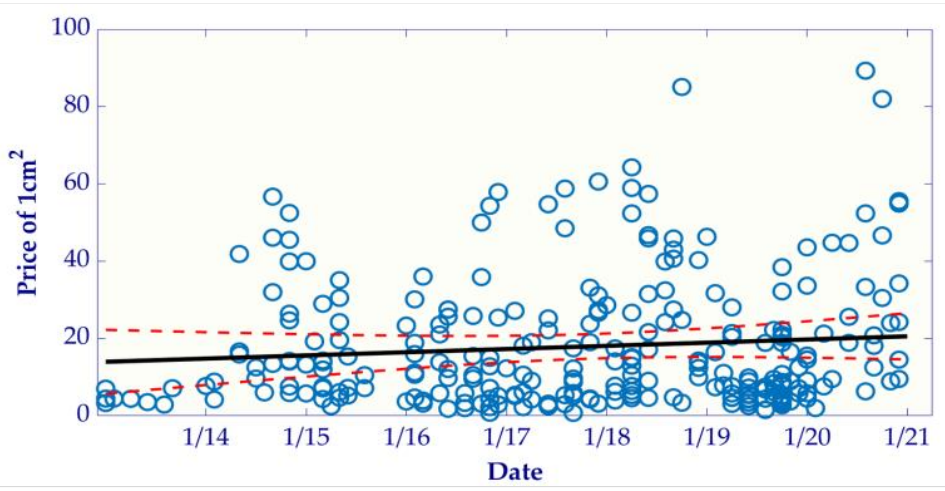

Figure 6. Regression line: all paintings.

Figures 1-5 illustrate the trend in prices for individual artists from our sample. For 13 artists, obtained values from individual auctions of their works can be seen in graphs, and the estimated trend line. Also, the confidence domain for the trend is shown.

Figure 6 shows the evolution of trend component of the time series between 2014 and early 2021 for the artists considered in this study.

Table 3 presents the estimated appreciation. The estimated annual growth in the prices of works of art in the Czech Republic is 4.003 percent.

Table 3. Results

\begin{tabular}{|c|c|c|c|c|c|c|c|}
\hline & $\begin{array}{c}\text { Year of } \\
\text { birth }\end{array}$ & $\begin{array}{c}\text { Year of } \\
\text { death }\end{array}$ & R2 & T1 & $\begin{array}{c}\text { Number } \\
\text { of works }\end{array}$ & $\begin{array}{c}\text { Work } \\
\text { technique }\end{array}$ & $\begin{array}{c}\text { Annual } \\
\text { change }\end{array}$ \\
\hline František T. Šimon & 1877 & 1942 & 0.010 & 0.7749 & 61 & Graphics & $2.81 \%$ \\
\hline František Tichý & 1896 & 1961 & 0.003 & -0.4334 & 77 & Graphics & $-1.58 \%$ \\
\hline František Gross & 1909 & 1985 & 0.004 & -0.2838 & 22 & Graphics & $-3.42 \%$ \\
\hline Josef Jíra & 1929 & 2005 & 0.163 & $1.8222^{*}$ & 19 & Graphics & $9.06 \%$ \\
\hline Kristian Kodet & 1949 & - & 0.105 & $1.9639^{*}$ & 35 & Oil & $7.62 \%$ \\
\hline Jiř́ Načeradský & 1939 & 2014 & & & & combined & \\
& 1892 & 1971 & 0.110 & $-1.8582^{*}$ & 30 & Graphics & $-43.46 \%$ \\
\hline Bohuslav Reynek & 1900 & 1970 & 0.076 & -0.9912 & 14 & Oil & $-17.75 \%$ \\
\hline Jan Slavíček & 1920 & 2011 & 0.173 & 1.5827 & 14 & Graphics & $11.29 \%$ \\
\hline Zdeněk Sýkora & 1926 & 2017 & 0.067 & $2.7984^{*}$ & 111 & Graphics & $15.24 \%$ \\
\hline Olbram Zoubek & & & 0.010 & $1.6522^{*}$ & 398 & & $4.003 \%$ \\
\hline sum & & & & & & \\
\hline
\end{tabular}

${ }^{1}$ The symbol ${ }^{*}$ indicates a test in which the zero hypothesis $\beta_{1}=0$ was rejected. 


\section{Discussion}

This article represents our pilot contribution to art market monitoring. In this contribution, a new way of obtaining data on the art market was introduced. Programmed Python procedures have been successfully employed for retrieving data from an art auction website for over 8 years. The designed and implemented platform enables automated data collection from the Platýz auction houses and their automatic processing within the longterm operation. Platform functionality can also be expanded in the future and, if necessary, vertical and horizontal scaling can be used to increase platform performance. The obtained time series allowed us to draw price graphs and perform selected statistical analyses.

The prices of works by Josef Jíra, Kristian Kodet and Olbram Zoubek statistically significantly increased, the prices of works by Bohuslav Reynek statistically significantly decreased.

From Table 3, we can see annual increases for works by František T. Šimon, Josef Jíra, Kristian Kodet, Zdeněk Sýkora and Olbram Zoubek - only increases of works by Josef Jíra, Kristian Kodet and Olbram Zoubek were statistically significant. The largest annual increase of 15.24 percent was with Olbram Zoubek. This price development was probably influenced by his death in 2017.

Annual increase of works by Josef Jíra was $9.06 \%$ and annual increase of works by Zdeněk Sýkora was found to be $11.29 \%$.

\section{Conclusions}

Knowledge of the expected annual interest rate of share and risks for financial investing on a stock exchange is sometime at our disposal. Estimates of the behavior of works of art prices, however, are not very available. In this work, we have attempted such estimates.

Through the parsing of the auction website, we have acquired data for several painters in the past 12 years containing the average size price in every sailed item.

However, further developments will be affected by inflation. The average inflation rate for 2019 was $2.8 \%$ and in 2020 it was 3.2\% (ČZSO, 2021). This value was the highest since 2012, when it reached 3.3\%. Between 2014 and 2016, the average inflation rate in the Czech Republic was at a very low level, as in most countries of the European Union (Hedvicakova, 2017; Hedvicakova \& Soukal, 2012). The inflation target is $2 \%$. But 2020 was affected by the Covid pandemic. This pandemic has also affected the art market. Due to restrictive measures, a number of auctions of works of art did not take place, and thus there was a massive drop in both the number of auctions and the funds spent. The situation with the Covid pandemic will affect the development of the art market this year as well as in the whole economy. Rising inflation can positively affect the art market as a store of value or, conversely, it can also negatively affect it, because there will be a decline in the purchasing power of the population (Svobodová \& Hedvičáková, 2015). The labor market will also significantly affect the art market. Due to the pandemic, the unemployment rate is rising and people are starting to save more for the next period. The forecast for the next period is therefore uncertain and much 
will depend on the measures of the Czech government. However, non-economic factors are also entering the art market, which may not be logical, but rather emotional.

The estimated annual increment of works of art prices in the Czech Republic was 4.003 percent. This value is higher than the inflation rate in the Czech Republic, which was between 1 and 3 percent in the years 2014 to 2020. In Scandela (1997) annual increment of works of art prices in Italy was found to be approximately the same as the interest rate. In Ashenfelter and Graddy (2002) and Ashenfelter and Graddy (2003), many authors and their real returns for art prices were compared. These values were found to lie between 0.55 percent and 5 percent for all cited authors, in publication Ashenfelter and Graddy (2003), this value was even 8 percent for one author, however, it was viewed as a unique value. These computed values correspond to the results of our research. In paper Pozdílková (2016) deals with analysis of the expected annual interest rate of mutual fund. The calculated estimate was around two percent.

Another interesting result of our research was a fact that the price trend is significant for most of the painters analyzed.

Acknowledgments: This contribution has been supported by the institutional support of the University of Pardubice, Czech Republic.

\section{References}

Agnello, R. J., \& Pierce, R. (1996). Financial returns, price determinants and genre effects in American art investment. Journal of Cultural Economics, 20(4), 359-383.

Ashenfelter, O., \& Graddy, K. (2002). Art Auctions: A Survey of Empirical Studies (June 2002). National Bureau of Economic Research.

Ashenfelter, O., \& Graddy, K. (2003). Auctions and the Price of Art. Journal of Economic Literature, 41(3), $763-786$. https://doi.org/10.1257/002205103322436188

Bialynicka-Birula, J. (2018). Changes in the global art market. Oeconomia Copernicana, 9(4), 695-714. https://doi.org/10.24136/oc.2018.034

Chanel, O. (1995). Is Art-Market Behavior Predictable. European Economic Review, 3(3-4), 519-527.

Hedvicakova, M. (2017). Key Study of Bank Accounts for Young People with Using Multi-Criteria Optimization and Fuzzy Analysis. Applied Economics., 49(36), 3599-3610, https://doi.org/10.1080/00036846.2016.1265073

Hedvicakova, M., \& Soukal, I. (2012). Retail Core Banking Services Costs Optimization. Procedia Technology, 1, 177-182. https://doi.org/10.1016/j.protcy.2012.02.033

Jun-ichi, I., \& Heinrich, W. U. (2016). Price and death: modeling the death effect in art price formation. Research in Economics, 70(3), 431-445. https://doi.org/10.1016/j.rie.2016.07.005

McAndrew, C. (2010). Fine art and high finance: expert advice on the economics of ownership. Bloomberg Press.

Mei, J., \& Moses, M. (2003). Art as investment and the underperformance of masterpieces: Evidence from 18752002. American Economic Review, 92(5), 1656-1668. https://doi.org/10.1257/000282802762024719

Onofri, L. (2009). Old master paintings, export veto and price formation: an empirical study. European Journal of Law and Economics, 28, 149-161. https://doi.org/10.1007/s10657-008-9094-2.

Pozdílková, A., \& Marek, J. (2016). Investment Funds - Estimation of Appreciation. In L. Balko (Ed.), Aplimat 2016: 15th Conference on Applied Mathematics: proceedings (pp. 938-946). Slovenská technická univezita v Bratislave.

Scandela, G., \& Scorcu, A. E. (1997). A Price Index for Art Market Auctions. Journal of Cultural Economic, 21, 175-196.

Stein, J. P. (1977). The Monetary Appreciation of Paintings. Journal of Political Economy, 5, 1021-1035.

Svobodová, L., \& Hedvičáková, M. (2015). Doing Business in the Countries of Visegrad Group. Procedia Economics and Finance, 34, 453-460. https://doi.org/10.1016/S2212-5671(15)01654-8

Szumilo, N., Wiegelmann, T., Łaszkiewicz, E., Pietrzak, M., Bernard, M., \& Balcerzak, A. P. (2018). The real alternative? A comparison of German real estate returns with bonds and stocks. Journal of Property Investment E Finance, 36(1), 19-31. https://doi.org/10.1108/JPIF-02-2017-0012 
Garay, U. (2019). Determinants of art prices and performance by movements: Long-run evidence from an emerging market. Journal of Business Research, 127, 413-426. https://doi.org/10.1016/j.jbusres.2019.03.057

ČZSO. (2021, January 17). https://www.czso.cz/csu/xe/prumerna-rocni-mira-inflace-v-cr-v-roce-2020-byla-32.

Platyz. (2020, January 17). Aukce obrazů i prodej. Retrieved January 17, 2021 from https://www.galerieplatyz.cz. 